1992

\title{
Privatization and Liberalization in the Middle East
}

Iliya Harik

Denis Sullivan

Marcie J. Patton

Fairfield University, mpatton@fairfield.edu

Follow this and additional works at: https://digitalcommons.fairfield.edu/politics-books

Copyright 1992 Indiana University Press

Content archived here with permission from the copyright holder.

\section{Recommended Citation}

Harik, lliya; Sullivan, Denis; and Patton, Marcie J., "Privatization and Liberalization in the Middle East" (1992). Politics Faculty Book and Media Gallery. 21.

https://digitalcommons.fairfield.edu/politics-books/21

This item has been accepted for inclusion in DigitalCommons@Fairfield by an authorized administrator of DigitalCommons@Fairfield. It is brought to you by DigitalCommons@Fairfield with permission from the rightsholder(s) and is protected by copyright and/or related rights. You are free to use this item in any way that is permitted by the copyright and related rights legislation that applies to your use. For other uses, you need to obtain permission from the rights-holder(s) directly, unless additional rights are indicated by a Creative Commons license in the record and/or on the work itself. For more information, please contact digitalcommons@fairfield.edu. 


\title{
C H A P T E R
}

\section{6}

\section{CONSTRAINTS TO PRIVATIZATION IN TURKEY}

\author{
Marcie J. Patton
}

Since the adoption of liberalizing, export-oriented economic reforms in Turkey in 1980 , a widespread consensus has developed on the need to reduce the public sector's share of economic activity and, correspondingly, to increase the participation and contribution of the private sector in the economy, particularly in the export arena. Both of these goals have been apparent in the post-1980 agenda of privatization which, fashioned under the leadership of Turgut Ozal, has included ambitious plans (although few offerings) for the sale of state-owned economic enterprises, and a complex system consisting of as many as five export-incentive regimes designed to stimulate and sustain an export drive by Turkish private manufacturers.

Privatization in Turkey has moved along these two tracks: the transfer of stateowned productive assets to private ownership, and the development of incentives to encourage and sustain an export drive propelled by large export trading companies in the private sector. Over time, however, results have lagged behind state intentions. Changes in the public-private mix have not been dramatic, and barriers to rapid privatization have emerged.

The purpose of this chapter is to offer some insight as to why the publicprivate division of labor remains so resistant to change, insight gained by assessing the record of privatization and by analyzing obstacles that have blocked the progress of reform.

\section{CONTINUITIES IN THE PRIVATE-PUBLIC DIVISION OF LABOR}

Since the establishment of a mixed economy and the creation of State Economic Enterprises (SEEs) over a half century ago, the question of an appropriate balance between the public and private sectors has remained politically controversial. In 
the early years of Turkish industrial development, state entrepreneurship was regarded as imperative for the establishment of an industrial base. During the etatist period in Turkey (1933-38) an institutional and legal framework for direct state intervention in the economy was established, and the state was assigned a strategic role in developing infrastructure and basic industries. However, the private sector was not de jure excluded from similar activities. Although the public sector quickly established dominance across a wide range of industrial activities, the private sector has registered steady growth and expansion, particularly during the years of planned import substitution industrialization (1960-80).

While the participation of the public sector in the economy does not appear to be shrinking, within the parameters of a mixed-economy framework, there has been a consistent and continuous secular trend showing movement of the private sector into a leading role in the production of consumer and investment goods. Since 1980 , the private sector has shouldered primary responsibility for the manufacture of Turkey's principal exports while the state has focused on such support services as: developing Turkey's infrastructure (roads, railroads, irrigation, and energy); providing key intermediate inputs (petrochemicals, steel, cement, paper) to private industry; offering export rebates; and promising to provide special facilities to assist exporters (by converting the State Investment Bank to an Eximbank and establishing marketing centers abroad). However, this division of labor is quite similar to that which prevailed during the period of import-substituting industrialization.

\section{THE CHARACTER OF INDUSTRIAL \\ DEVELOPMENT}

The importance of industrial development can be seen in the rather dramatic shift in emphasis from agriculture to industry. The share of GDP (Gross Domestic Product) contributed by agriculture began to fall swiftly in the sixties ${ }^{1}$ when planned import-substitution industrialization was introduced. In terms of the rate of GDP growth, since the 1960s when industrialization was begun in earnest, industry has tended to make a more substantial contribution to GDP than both the agricultural and services sectors. ${ }^{2}$ Of particular note is that until the period of economic stagnation and crisis in the latter half of the 1970s, the rate of increase in GDP by agricultural production fell well behind the contribution of industry.

After 1980, industry surged ahead as the leading economic sector contributing to the growth rate of GDP between 1980 and 1984 at nearly triple the difference from agriculture (compare 7.2 percent with 2.5 percent). Since 1984, agriculture has grown only half as fast as industry. From the tables it can be seen that, regardless of whether the strategy of either import-substitution industrialization or export-promotion industrialization was preferred, rapid expansion of the industrial sector has clearly been the focus of development efforts in Turkey. 


\section{STRUCTURE OF THE MANUFACTURING SECTOR}

The principal beneficiary of the industrial development drive in Turkey has been the manufacturing sector, with mining, energy, housing, tourism, and banking services tending to attract greater investment attention only of late. There has been a clear secular trend in the direction of emphasizing production of intermediate and investment goods over consumer goods. Changes in the distribution of the labor force across sectors reflect this trend as well. In the early phase of ImportSubstitution Industrialization (ISI), consumer goods accounted for over half of value added in manufacturing (51.1 percent in 1963). However, during the deepening phase of ISI in the 1970 s, the contribution of consumer goods to value added declined, falling to 33.4 percent by 1980 while the contribution of intermediate and investment goods to value added increased significantly. ${ }^{3}$ While consumer industries still carry substantial weight in the manufacturing sector, Turkish manufacturing has undergone considerable diversification and deepening in the direction of more technologically advanced and specialized branches of production. It is important to recognize that these transformations in Turkish manufacturing predate the introduction of the liberalization reforms and emphasis on exports of manufactured goods.

\section{ECONOMIC PERFORMANCE OF THE PUBLIC AND PRIVATE SECTORS}

A comparison of the public and private sectors shows an interesting divergence in concentration of manufacturing activity (see table 1). The state sector exhibits a strong preference for holding on to consumer-goods industries over time, but has shifted its production emphasis to its intermediate-goods industries. The private sector, in terms of production, employment, and value added, evidences a transformation away from consumer towards intermediate- and investment-goods industries with a pronounced movement towards investment-goods industries at the expense of consumer industries. However, both the state and private sectors are converging in their emphasis on intermediate goods production.

Structural changes in private as compared to public manufacturing in Turkey are shown in the following tables. Table 2 uses the number of firms in each sector as an indicator of the concentration of ownership. Three significant observations emerge: First, contrary to assertions that capital was becoming increasingly concentrated throughout the 1970s, the number of privately owned firms more than doubled between 1971 and 1980 with all sectors (except for tobacco) multiplying in number of firms. ${ }^{4}$ Second, this trend is dramatically reversed after 1980 when the number of private-sector firms within a short period of three years falls to below the number existing in 1971. This reflects the huge number of bankruptcies 


\section{TABLE 1}

The Structure of Manufacturing in the State and Private Sectors, $1955-83$ (percent)

Sources: Robert Bianchi, Interest Groups and Political Development in Turkey (Princeton, N.J.: Princeton University Press, 1984), p. 48; State Institute of Statistics, Turkiye Istatistik Yillig 1985 (Ankara: Devlet Istatistik Enstitusu Matbaasi, 1985), pp. 256-67.

which occurred following the introduction of the 1980 reforms. Third, up to 1980 privately owned firms multiplied in the intermediate and investment fields, and public-sector firms increased in consumer- and investment-goods industries; however, in the early 1980s, the number of public-sector firms rose in the intermedi- 
ate- and investment-goods industries such that there was an overall increase in the number of public-sector firms from 1980 to 1983. The same trend towards increasing concentration on intermediate and investment goods is apparent in the private sector when a comparison is made between 1971 and 1983; the number of consumer-goods firms is down but intermediate and investment industries have picked up.

In table 3, firm size as determined by the number of workers is presented. Of particular note is that public-sector firms employ many more workers per firm than their counterparts in the private sector (with the exception of furniture, leather and rubber products). Overemployment in the public sector has been an oft-noted political patronage device that the 1980 reforms attempted to curb, and judging from table 3, a modest degree of restraint has been exercised. Using 1980 as a threshold, the public-sector firms have trimmed and scaled back the number of their employees whereas the private sector, while halving the number of firms, has doubled the average number of workers per firm.

However, even after 1980, the scale of industry remains comparatively larger in the public than the private sector. Since 1980, the larger public-sector firms are in the intermediate-goods industries while incremental growth in the size of private-sector firms appears to be favoring the investment-goods sector. This division of labor suggests that the state remains an important supplier of industrial materials to the private sector (especially petrochemicals, nonmetallic minerals, and metal products). It also suggests that the private sector is expanding its scale of production in the capital-intensive sectors of transportation equipment and heavy machinery as well as doubling firm size between 1980 and 1983 in most of the consumer goods industries.

Productivity of the private and public sectors increased markedly after 1970. Most remarkable is the more than tenfold increase in value added per worker in both the private and public sectors (with the exception of state manufacturing of consumer goods) between 1971 and 1980, given that negative growth rates were experienced in the late 1970s. Between 1980 and 1983, there is a two- to threefold increase in value added per worker for both sectors. ${ }^{5}$ The public sector leads productivity in intermediate goods while the private sector is clearly making significant strides in investment goods and appears to be closing the gap with the public sector for consumer goods.

Among the consumer-goods industries, the private sector shows much greater productivity (except for beverages) than the public sector, which has a higher worker per firm ratio.

Since 1980, there appears to be strong sectoral competition between the state and private sectors in most consumer industries (with the exception of clothing and beverages), but a more scattered picture emerges when the intermediate and investment industries are examined. Paper, rubber, nonmetallic minerals, and metal products appear to be competitive intermediate industries, as are metal products and nonelectrical machinery products in the investment industries. There appears to be a tacit division of labor in which the private producers have opted for man- 


\section{2 / Privatization and Liberalization in the Middle East}

ufacturing consumer and investment goods and the public sector has focused on intermediate goods. Even within these branches of industry (consumer, intermediate, investment), there are clearly certain sectors reserved to each. Hence, in spite of the promises of the new economic model to radically restructure the privatepublic balance, the diversification of manufacturing still reflects a tacit compartmentalization of the public and private domains.

\section{THE STATE AS A PRODUCER}

The economic policies adopted soon after the War of Independence in 1923 reflected the "liberal," procapitalist orientation of the indigenous business community. State intervention in the economy took the form of fostering the development of the private sector through the granting of virtual monopoly rights to private entrepreneurs, the establishment of the Business Bank (Is Bankasi), and other sundry incentives. However, the advent of the Great Depression strengthened proponents of stronger protectionist controls, proponents who were responsible for introducing the etatist policies of the 1930s. Between 1933 and 1938, a number of public enterprises were founded in the banking, manufacturing, agriculture, transportation, mining, and energy sectors. During the late 1930s, the state emerged as the major producer in the economy in addition to dominating investments. ${ }^{6}$

The initial motivation for establishing SEEs was to accelerate economic development and to contribute to the development of the private sector. The SEEs, however, were quickly subject to political interference. Every ruling party in Turkey has used the SEEs as a patronage device to distribute benefits to its supporters. While by law the SEEs were promised administrative and financial autonomy, over the years the hiring and promotion of SEE managers was governed by partisan considerations, as was the practice of overemployment. Managerial control of SEEs was further undermined by the power of the cabinet to fix the prices of basic goods and services. Because the prices of SEE products were not market determined but served sociopolitical objectives (such as supplying cheap raw materials and intermediate inputs to the private sector, and inexpensive goods and public services to the populace), the SEEs were not self-financed. Financially the SEEs drew on public funds (transfers from the Central Bank and Treasury funds) to cover their losses as well as their need for investment credits.

During the foreign-exchange and debt crisis of the late 1970s, the number of SEEs reporting losses and the size of these losses ballooned. Despite the adverse impact of global oil-price increases in this period, SEE investment programs were expanded, militant wage demands of public-sector workers were met, excessive hiring practices were continued by weak coalition governments, and SEE prices of energy and other basic products continued to be subsidized. Consequently, the financial burden of the SEEs on the Treasury rose rapidly, worsening the deterioration in the economy and contributing to the view that SEE reform was essential.

The post-1980 privatization plans for the public sector have been targeted at 


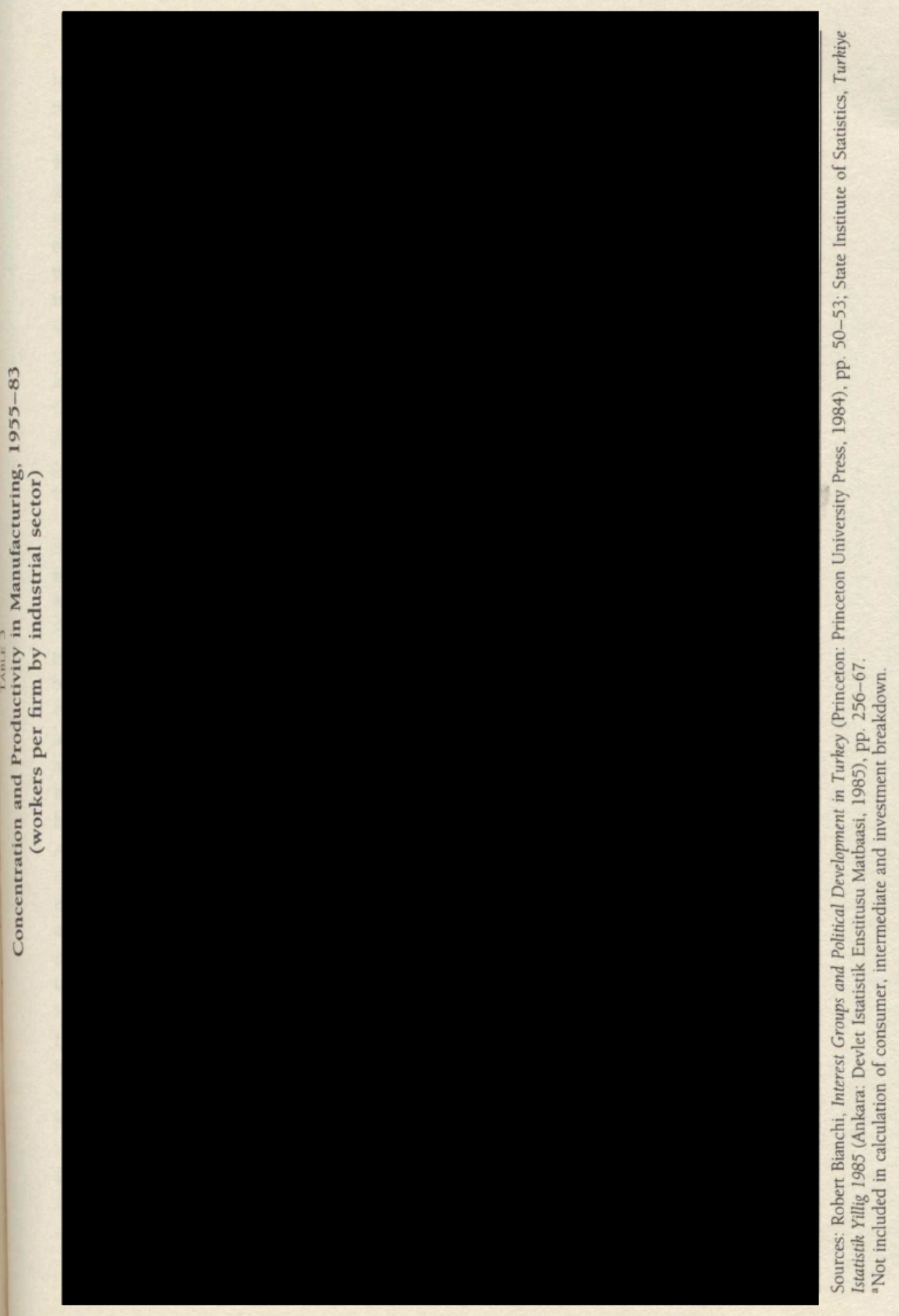




\section{4 / Privatization and Liberalization in the Middle East}

making the SEEs financially self-sufficient, with a view to reducing the number of SEEs in the long run. There are in effect two purposes at work: to reduce the burden that SEEs deficits place on the central government's budget, and to improve the productivity as well as financial performance of individual SEEs in order to make them attractive for sale. The principal mechanism used both to ready the SEEs for sale and to enhance their profitability and competitiveness in the economy has been the reform of SEE pricing policy. The SEE practice of selling goods and services at subsidized prices has been abandoned. To cover operating deficits and to generate new funds for investments, the prices of SEE products have been decontrolled. In short, overpricing SEE products has proved to be a quick way to ensure an operating profit.

\section{EFFORTS TO REFORM PRICING AND IMPROVE PRODUCTIVITY OF SEES}

Financially, the performance of SEEs between 1980 and 1986 improved considerably. By raising prices, SEEs not only began registering an aggregate profit in 1984, but, in addition, the SEE's share of the public-sector borrowing requirement was lowered. However, the financial performance of SEEs is still governed by political considerations. National and local elections in 1987 and 1988 caused delays in price increases for public-sector goods as well as in the passage of a huge wage increase for public-sector workers. ${ }^{7}$ As a result, SEE losses rose, and the SEE borrowing requirement, which had been falling, climbed from 4.3 to 4.7 percent of GNP in 1987. The central government had to meet the operating losses of the SEEs with large budget transfers. The pricing policies of SEEs have been manipulated to serve the ambitions of political leaders. The SEEs continue to be blamed as a major source of high inflation and as an important contributor to the publicsector deficit, much as they were in the 1970s.

While improvements in the financial performance of the SEEs have come primarily through price hikes, ${ }^{8}$ efforts to improve the productivity of SEE's have been handicapped by bloated employment rosters and antiquated equipment. Although measures to reform employment practices (by requiring the hiring of new personnel based on term contracts) were instituted in 1987-88, the SEEs continue to be overmanned by 10 to 25 percent. In addition, huge investments are needed to modernize the outdated facilities and equipment of SEEs. As the decision to make a telecommunications company, Teletas, the first candidate for privatization indicates, plans to privatize SEEs hinge on selling off modernized, profitable firms. ${ }^{9}$ The amount of financing that the SEEs have utilized for their investment programs shot up by nearly 400 percent between 1984 and 1988. Unfortunately, the overall financing requirements of the SEEs have gone up at the same time that the government is concerned with reducing public investments to control inflation. 


\section{OBSTACLES TO PRIVATIZATION}

The actual progress of selling off enterprises has been slow. The task is enormous. The SEEs account for approximately 40 percent of Turkey's industrial production and 60 percent of fixed investments. However, the more insuperable obstacles are not economic but political. Public awareness of and disgruntlement with the inflationary costs of preparing the SEEs for sale, by hiking prices and spending to invest in modernizing plants, has kindled a political debate over the way in which state assets will be sold and how the proceeds of selling off state assets will be spent. While there is popular resentment over the inflationary effects of SEE reforms, there seems to be little controversy over the desirability of state intentions to turn loss-making enterprises into economically efficient, rationally run, profitable concerns. Rather, the focus for popular discontents is the second phase of the privatization program, the selling off of state enterprises. At issue is whether these enterprises should be sold, and to whom.

In 1986, a legislative framework for privatization was instituted. Once a SEE is designated for privatization, it automatically becomes a corporation and its shares are placed under the managerial control of the Mass Housing and Public Participation Administration (MHPPA) whose board consists of eleven ministers under the chairmanship of the prime minister. As of September 1989, two SEEs, eleven subsidiaries, five banks, and the state shares of thirty-eight public companies had been transferred to the MHPPA. ${ }^{10}$ The first privatization was launched in February 1988 when 22 percent of Teletas, a 40 percent state-owned telecommunications company, was sold through a public offering. However, because of stagnation in the Istanbul Stock Exchange throughout 1988, the government turned to sales of block shares to foreign investors. The opposition parties on the left as well as the right in Turkey have registered strong opposition to this method of sale.

In 1989, the government sold block shares of five cement plants belonging to the state-owned Citosan to France's SCF (Société des Ciments Français) for \$105 million and 70 percent of USAS (Turkish Air Catering Service) to SAS Partner, a subsidiary of Scandinavian Airlines System, for $\$ 14.5$ million. In early 1990, the opposition True Path Party and Social Democrat Populist Party challenged the legality of the sales in separate cases brought before administrative courts in Ankara. The plaintiffs argued that a 1987 government directive required that privatized firms be offered first to Turkish nationals and then to foreigners. The court in turn annulled both deals and also rejected maneuverings by the government to revise its directive, allowing for block sales to foreigners and to make the changes retroactive. Ozal's government has argued the benefits of block sales to foreigners by asserting that they attract investment capital to Turkey and bring in technology and managerial expertise. ${ }^{11}$ They also point out that capital markets are weak in Turkey and that the conditions of sale to foreign companies have included provisions for delayed public offerings. ${ }^{12}$ 
Nevertheless, the privatization program has come under growing criticism for selling national assets to foreigners. Members of the opposition had earlier made an issue of plans for selling a state-owned air charter and cargo company to a foreign company at what was regarded as too cheap a price. The sale was dropped. Challenging block sales to foreigners is a major challenge to the privatization program. The government must again discuss the privatizing alternative of returning to the sale of public shares on the stock market. Resort to this method, however, due to the underdeveloped state of capital markets in Turkey, is likely to slow the process of state disinvestment.

The controversy over transferring state assets to foreigners has also increased public sensitivity to the issue of who will benefit from the sale of SEEs. Opponents of privatization claim that the state will sustain losses of income in the future from having sold off the more efficient SEEs. They can easily find examples to support their position. The announced decision in spring 1990 to commence privatizing the state tourism company, Turban, starting with the sale of Turban's marinas, caused considerable consternation as the marinas are the most profitable of Turban's assets. By privatizing the marinas, insiders predict that the company will be headed for heavy losses in the coming years. Moreover, critics of the sale of state assets have argued that privatization amounts to nothing more than a debt-payment mechanism whereby the revenues of the shares sold will be used to service the Turkish debt. Proceeds from the sale of state assets are supposed to be deposited with the MHPPA and the Treasury, but the government has been accused of using the revenues from these sales to cover shortfalls in the budget. In fact, President Ozal was recently quoted as saying: "If the state wants to close its budget gap then it has to sell shares of its enterprises on the exchange."

Opposition to privatization has become more clamorous, particularly as the sale of the giant state conglomerates Petkim (petrochemicals), Erdemir (iron and steel), and Sumerbank (textiles) moves to the top of the privatizing agenda. What was an issue of the domestic repercussions of market-based, economic reforms is peing transformed into a hotly contested political debate over the highly sensitive issues of dependency on foreign multinationals and the denationalization of Turkfy's industrial base.

\section{PASSAGE TO A COMPETITIVE MARKET ECONOMY}

Since 1980, the Turkish economy has turned in an impressive performance based largely on export-led growth. Growth rates climbed to 8.0 percent and 7.5 percent in 1986 and 1987 respectively, and the country's exports have soared from $\$ 2.9$ billion in 1982 to $\$ 11.43$ billion in 1988. Where once the main export was hazelnuts, over three-fourths of the 1987 exports were industrial goods, with agricultural goods accounting for only 18 percent of the total. In addition, the current account deficit, an important barometer for international bankers, has been falling. 
Heavily indebted in 1979, Turkey by the mid-1980s had become the leading recipient of World Bank B-loans, signifying that the international financial community not only has restored Turkey's creditworthy status but also had confidence in Turkey's economic performance into the foreseeable future. However, the transition to a competitive market economy has not been smooth.

\section{ENGINES OF THE EXPORT DRIVE: THE FOREIGN TRADING COMPANIES}

Former Prime Minister, and now President, Ozal and his handpicked coterie of technocrats manning key government posts in banking, planning, treasury, and foreign-trade spheres had envisioned reliance on Turkey's top holding companies for leadership in adapting to export-oriented competition. The clearest manifestation of this has been Ozal's own pet project, the creation in 1983 of general trading houses to which special export privileges were granted. The idea was borrowed from the Japanese style of state-business collaboration, as exemplified by the Sogo Shosha trading companies, and was intended to be of advantage to Turkey's large industrial capitalists. Specifically, "Turkish exporters who realized an annual export volume of $\$ 30$ million of which at least 75 percent consisted of manufactured, and processed foods were granted the title of Foreign Trade Corporate Company [with] special credit facilities, interest-rate reductions, and tax rebates." ${ }^{13}$ In April 1988, the Turkish government raised the export requirement for FTC (Foreign Trade Company) designation to $\$ 50$ million. The most important of the special incentives granted to the FTCs have been a 6 percent tax rebate over export volume and exclusive permission to import from and engage in special barter (countertrade/buy-back operations) with Eastern bloc countries. ${ }^{14}$ Among the anticipated and desired consequences of offering extra export incentives to these trading companies has been the concentration of private-sector exporting power in the hands of a few as most of the trading houses constitute an arm of the top Turkish holding companies in the private sector.

Have the FTCs lived up to expectations? In 1981, these foreign trading companies accounted for only 9 percent of Turkey's exports, but by 1985 this figure had soared to 36.0 percent and continued climbing to over 50 percent in 1988 . However, while these trading companies are considered to be the primary engines of the export trade, they have been highly dependent on the government for an array of special export subsidies and incentives. Moreover, there is little indication that the government has been able to wean these companies from the continued reliance on its favors.

In early 1987, the Foreign Trade Department of the Treasury admonished a number of the large export companies for accepting incentives in 1986 but then falling short of requirements to export $\$ 30$ million of merchandise to qualify for special privileges. The Foreign Trade Department went on to remonstrate these companies further for not meeting the requirement that at least 75 percent of their 
exports be composed of industrial goods. ${ }^{15}$ In fact, because most Turkish exporters appear to be strongly responsive to subsidies and incentives, the government has become apprehensive about reducing export credits, fearing that this would likely precipitate a fall in exports. Indeed, it is with this concern in mind that the government-in view of the need to eliminate overt subsidies on exports by the end of 1988 (due to signatory agreements with GATT and with an eye toward Turkey's impending membership in the EEC) - decided to switch to a system of indirect export incentives in 1989. The main features of the new incentives to encourage exports are cheap Eximbank credits, subsidized energy, and premium payments out of the extrabudgetary Support and Price Stability Fund.

\section{RELUCTANCE OF BIG BUSINESS TO ADJUST}

Owners of the largest holding companies in Turkey, most of whom belonged to the pre-1980 coalition of import-substituting interests and on whom Ozal's strategy to a large extent has relied, have been protesting since 1980 that adjustment to the new economic rules of a competitive marketplace takes time and that Ozal's policies push them too far, too fast. On a number of occasions, leading businessmen have mobilized to oppose Ozal's policies. In 1982, a contingent of key businessmen travelled to Ankara to pressure the military government to remove then Deputy Premier Ozal and to relax Ozal's economic policies, including abandonment of his tough opposition to governmental bailouts of bankrupt firms. Ozal was subsequently fired by the generals. Following his dismissal, Ozal founded the Motherland Party and was returned to power as Prime Minister after the 1983 return to democracy elections. However, Ozal's policies remain controversial among businessmen concerned about the rapid reduction in state protection. Prior to the 1987 elections, newspapers reported significant campaign contributions from big businessmen being made to support the True Path Party, led by former Prime Minister Demirel who is regarded as a strong supporter of industrialists favoring continued government subsidies and other forms of protection.

In a 1988 interview with Euromoney magazine, Yusuf Ozal, brother of Turgut Ozal and at the time minister for planning, treasury and foreign trade, commented that for Turkish industrialists the pre-1980 business climate had meant, "High protection, high profit, easy money. Export led growth, however, means competition, it means selling outside of Turkey in a difficult environment. Not all businesses have managed to turn round to exports. They are still doing import substitution." 16 With the exception of a few holding companies whose activities are concentrated principally or solely in the textile and construction sectors, Turkish industrialists have not abandoned their ISI-orientation. ${ }^{17}$ Many of the top Turkish exporters continue to produce largely for the domestic market. For example, Turkey's two largest industrial conglomerates, Koc and Sabanci Holding companies ". . . exported only about six percent of their turnover in 1986 and are largely 
oriented to the home market." ${ }^{18}$ And yet, Koc Holding owns the trading company Ram and Sabanci Holding owns Exsa, which ranked third and fifth respectively among the top ten exporting groups of 1986 .

A study published in 1986 by the Istanbul Chamber of Industry suggests that many of Turkey's large firms have been finding it difficult to adjust to the new competitive market rules. An increasing number of the Fortune 500 companies of Turkey have been experiencing net losses, 35 in 1984 and 55 in 1985. And while inflation in 1985 was averaging 45 percent, real average earnings of these companies came to 42.6 percent-an overall decline in real average earnings. ${ }^{19}$ The scaling back and elimination of export subsidies in 1989 and continued high inflation (70-plus percent) are not likely to brighten prospects for high profits in the future. $^{20}$

In spite of the policy preferences of the state technocrats, the transition to a competitive market economy is not exclusively the province of the big holdings. Export success is not simply a function of firm size. ${ }^{21}$ In fact, a comparison of the 500 largest firms with firms in the economy as a whole reveals an interesting trend with respect to exports. ${ }^{22}$ Whereas the Fortune 500 Turkish firms accounted for 63.7 percent of industrial exports in 1983 , this figure had dropped to 45.1 percent by 1987 . Even in terms of total exports, the Fortune 500 firms generated 42.8 percent of the total in 1983 and 36.9 percent in 1987. It would appear that Ozal's project of establishing foreign trading companies has proved to be an expeditious method for getting exports up by encouraging the output of smaller businesses to be consolidated with that of the big export houses. The FTCs have been useful as a marketing outlet for the products of small- and medium-sized enterprises. However, the above figures also suggest that the largest firms in the Turkish economy are not wholely converted to manufacturing exportable goods. More often than not, the large industrial groups (including those linked with a FTC) have a foot in both camps-producing mainly for the domestic market and trading exportable goods, some of which may be produced by a subsidiary and the rest acquired from smaller manufacturers in order to take advantage of the sizeable export subsidies and rebates.

The Ozal government has recognized that the FTCs are more trading entities than outlets for the exports of Turkey's big industrial producers, but is not sure how to alter this. After direct tax rebates were discontinued at the end of 1988 , officials introduced a package of export incentives directed at the manufacturers of export goods. This approach failed to bring up exports in 1989. Incentives for 1990 were directed once again at the entities doing the actual exporting, namely the FTCs.

The export-led growth model has generated a variety of support groups, especially from those with a proven ability to compete in world markets. Nonetheless, given that the business community in Turkey has been accustomed to producing under an umbrella of state protectionist measures, it should not be too surprising that even as sectoral successes are reported, many industrialists (includ- 


\section{0 / Privatization and Liberalization in the Middle East}

ing ISI-oriented holdings) are still inclined to look to the state to provide incentives to ease the transition. Nor is it unusual that those who are insistent that the state continue to offer incentives also support Turkey's application for full membership in the EEC. ${ }^{23}$

The most significant change that the post-1980 reform measures have wrought is a change in private-sector attitudes. Businessmen accept that the transition to a competitive market economy is not reversible and that they must seek ways to make their enterprises competitive. For most industrialists, however, the preferred and least painful way to survive in a more competitive environment is for the state to help shoulder the cost of adjustment. Hence the issue of to whom the state should offer export incentives and subsidies remains a subject of unresolved debate.

\section{CONCLUSION}

The post-1980 privatization program in Turkey has been aimed at redrawing the boundaries between the public sector and the private sector. Yet, while the intended purpose of the post-1980 policy reforms was to bring about a radical structural transformation in the participation and contribution of the private and public sectors to the Turkish economy, a major redivision of labor is not in evidence. A comparison of the economy before and after 1980 showed continuation of preexisting patterns and trends and evidence of incremental rather than radical structural change. The Turkish case is illustrative of the difficulties of bringing about a redivision of labor in a mixed economy.

An examination of the principal privatizing strategies for rolling back the public sector showed that while some progress has been recorded, there has emerged a ground swell of popular opposition to the sale of enterprises to foreigners and concern over how proceeds from sales will be applied. Mounting criticism over the sale of state assets is likely to restrain rapid privatization along this track. In addition, efforts to induce the private sector, especially the large holding companies, to increase exports have been frustrated by the reluctance of many of these business interests to abandon import-substituting interests and turn seriously to exports. Businessmen have been insistent and effective in ensuring that export incentives be continued. By turning the debate from whether incentives should be offered to the question of the type of incentives which should be offered, business has effectively compelled the state to retreat from rapid privatization along this track. Contrary to optimistic predictions that the barriers to privatization will dissipate once public opinion and businessmen accept that a realignment of the public and private sectors is necessary, the Turkish case shows how the strategies chosen for shifting a mixed economic system in the direction of a private-sectorled economy are shaped by policy debates that can redefine privatizing ends as well as means. 


\section{Notes}

1. The Economist Intelligence Unit, Turkey, 1989-90, p. 16.

2. Union of Chambers of Commerce, Industry, and Commodity Exchanges of Turkey, 1923-1982, Cumhuriyet Doneminde Istatistiklerle Turkiye (Ankara: Union of Chambers, 1982), table 18; State Institute of Statistics, Turkiye Istatistik Yillig 1987 (Ankara: Devlet Istatistik Enstitusu Matbaasi, 1987), p. 92.

3. Whereas intermediate goods accounted for 32.5 percent of value added in 1963 by 1980 they accounted for 48.7 percent. By 1980 investment goods contributed 17.6 percent of value added as compared to 14.6 percent in 1963.

4. Of course, just because there was a growth in the number of firms does not mean that ownership was dispersed. Indeed, there is considerable evidence that a small number of holding companies control the firms which dominate industrial production in Turkey.

5. Robert Bianchi, Interest Groups and Political Development in Turkey (Princeton: Princeton University Press, 1984), pp. 50-53; State Institute of Statistics, Turkiye Istatistik Yillig 1985 (Ankara: Devlet Istatistik Enstitusu Matbaasi, 1985), pp. 256-67. Bianchi, Interest Groups, pp. 50-53; State Institute of Statistics, Turkiye, pp. 256-67.

6. Not only has the state remained influential in the post-1980 economy by virtue of its sizeable ownership role, but the share of the state in fixed investments remains high. Since 1980, the state has directed its investments primarily to sectoral investments in energy, in transportation and communication (for infrastructure-related projects), and in decreased investment in manufacturing. Yet, the state still contributes at least 25 percent of total investment in manufacturing. State investment in manufacturing stood at 31.0 percent of total investment in manufacturing in 1985 and 26.0 percent of total in 1986 (Turkish Industrialists' and Businessmen's Association, The Turkish Economy, 1987, p. 13). Moreover, a special survey on Turkey pointed out that via an extra-budgetary fund financed by special tax levies the state contributes to fixed investments in housing even more than is actually recorded; see "Getting Ready for Europe," Economist (June 1988): 12.

7. To woo rural voters, generous increases in agricultural commodity support prices were also approved in 1987.

8. A portion of the increased profitability of SEEs can be attributed to managerial improvements which include changes in personnel and greater decisional autonomy. However, SEE managers are by no means insulated from politics.

9. According to Cengiz Israfil, formerly in charge of the privatization program, "Citosan's cement business looked to be a good first candidate but when we looked at it from a marketing point of view, we realized it was hard to get people excited about a cement plant with old equipment when we had Teletas which was selling high technology" (Euromoney, Special Supplement, May 1988: 21).

10. Finance (September, 1989): 34.

11. Between 1954 and 1979, the value of foreign investment in Turkey amounted to only $\$ 228$ million. Between 1980 and 1986, a total of $\$ 1575$ million in foreign investment entered Turkey. However, approximately one third of this consisted of unsecured commercial loans. The remainder of this investment amount represents actual capital inflows, which for the most part have been directed to augmenting existing holdings. In spite of the tremendous reduction in the bureaucratic red tape pertaining to foreign investment regulations and application procedures since 1980, political uncertainties and inflationary pressures throughout the 1980s have dissuaded interested investors from embarking on major new undertakings. 


\section{2 / Privatization and Liberalization in the Middle East}

12. For example, according to the sale agreement with SCF, 40 percent of the shares of one of the cement factories to be acquired would be sold to the Turkish public within five years.

13. Foreign Trade Association of Turkey, Brochure, 1984, p. 5.

14. SEE's also shared in this exclusive privilege of trade with the USSR and East European countries. The share of COMECON countries in Turkey's total exports was 4.2 percent in 1985 and 5.2 percent in 1988, and their share in Turkey's total imports was 5.8 percent in 1985 and 7.7 percent in 1988 (Istanbul Chamber of Commerce, Economic Report, 1989:72, 81).

15. Diplomatic Pulse, no. 4625-274, 6 April 1987.

16. Euromoney, Special Supplement, May 1988: 28.

17. Businessmen in the textile and construction industries became active in selling their goods and services outside Turkey during the 1970s. Even with the exchange-rate bias against exports during the late 1970s, the large firms (Mensucat Santral, Altinyildiz, and Narin Mensucat in textiles; Kutlutas and ENKA in construction) continued to seek export opportunities.

18. Financial Times, Survey of Turkey, 16 December 1987: 2. list.

19. This is if the two largest state-owned companies are omitted from the Fortune 500

20. Naturally the Gulf War has had a devastating effect on the Turkish economy; however, the focus of this paper is on the prewar period 1980-90.

21. Indeed, adjustment to producing for export, across sectors, has been uneven. Four commodity groups (textiles, iron and steel, leather, and chemicals) account for just over 50 percent of Turkish exports.

22. "Turkey's 500 Large Industrial Establishments," Journal of the Istanbul Chamber of Industry (October 1988): 40.

23. In a joint declaration signed by members of the Turkish business community concerned about the too rapid removal of protectionist measures, a number of the preparatory conditions for Turkish membership proposed by European members are criticized as "asking for too much without promising anything tangible in return"; see Turkey Monitor, no. 41, 20 October 1989: 8-9. 